\title{
Optimization and Enhancement of Decorative Glass Organic Coating Properties Containing Ulexite Mineral
}

\author{
Nil Acaral $1^{1 *}$, Rabia Oktay ${ }^{2}$ \\ 1* Yildiz Technical University, Faculty of Chemical and Metallurgical Engineering, Departmant of Chemical Engineering, İstanbul, Turkey, (ORCID: 0000-0003-4618- \\ 1540), nilbaran@gmail.com \\ ${ }^{2}$ Yildiz Technical University, Faculty of Chemical and Metallurgical Engineering, Departmant of Chemical Engineering, İstanbul, Turkey, (ORCID: 0000-0002-0906- \\ 1083), rabiaokty@gmail.com
}

(First received 7 March 2021 and in final form 17 October 2021)

(DOI: $10.31590 /$ ejosat.892579)

ATIF/REFERENCE: Acaral1, N. \& Oktay, R. (2021). Optimization and Enhancement of Decorative Glass Organic Coating Properties Containing Ulexite Mineral. European Journal of Science and Technology, (27), 665-669.

\begin{abstract}
Nowadays, glass coatings have a wide range in the industry and have been an important research topic. It is preferred to use glass as a decorative object especially in daily life. In this study, decorative glass coating was tried to be developed with the use of ulexite. The ulexite mineral is a mineral consisting of white round crystalline masses. Test results (visual, hydrophobicity, adhesion tests, etc.) showed that the use of ulexite with additives (potassium dichromate and surfactant) positively affects the coating properties in decorative glass coating production. In the experimental study, Taguchi Method was used as an optimization method and the results were analyzed to improve cost and quality to determine the optimum process parameters. TG-DTA (Thermal Gravimetric Differential Thermal Analysis) and SEM (Scanning Electron Microscope) methods were used to characterize the thermal properties and physical morphological properties of the coatings prepared, respectively. It was observed that the additives added in the coatings prepared did not have a negative effect on the structure of the coating. As a result, the additives used improved the properties of glass coatings and the results showed that additive coatings prepared in various industries can be evaluated.
\end{abstract}

Keywords: Ulexite, Glass, Coating, Surfactant.

\section{Üleksit Minerali İçeren Dekoratif Cam Organik Kaplama Özelliklerinin Optimizasyonu ve İyileştirilmesi}

$\ddot{O} \mathbf{z}$

Günümüzde cam kaplamalar sektörde geniş bir yelpazeye sahip ve önemli bir araştırma konusu olmuştur. Özellikle günlük hayatta camın dekoratif obje olarak kullanılması tercih edilmektedir. Bu çalışmada üleksit kullanılarak dekoratif cam kaplama geliştirilmeye çalışılmıştır. Üleksit minerali, beyaz yuvarlak kristal kütlelerden oluşan bir mineraldir. Test sonuçları (görsel, hidrofobiklik, yapışma testleri vb.) dekoratif cam kaplama üretiminde üleksitin katkı maddeleri (potasyum dikromat ve yüzey aktif madde) ile kullanımının kaplama özelliklerini olumlu yönde etkilediğini göstermiştir. Deneysel çalışmada, optimizasyon yöntemi olarak Taguchi Yöntemi kullanılmış ve optimum süreç parametrelerini belirlemek için maliyet ve kaliteyi iyileştirmek için sonuçlar analiz edilmiştir. Hazırlanan kaplamaların termal özelliklerini ve fiziksel morfolojik özelliklerini karakterize etmek için TG-DTA (Termal Gravimetrik Diferansiyel Termal Analiz) ve SEM (Taramalı Elektron Mikroskobu) yöntemleri kullanılmıştır. Hazırlanan kaplamalara eklenen katkı maddelerinin kaplamanın yapısına olumsuz bir etkisi olmadığı görülmüştür. Sonuç olarak, kullanılan katkı maddeleri cam kaplamaların özelliklerini iyileştirmiş ve sonuçlar çeşitli endüstrilerde hazırlanan katkı kaplamalarının değerlendirilebileceğini göstermiştir.

Anahtar Kelimeler: Üleksit, Cam, Kaplama, Yüzey Aktif Madde.

* Corresponding Author: nilbaran@gmail.com 


\section{Introduction}

Glass is a highly preferred material as colored coatings in industrial applications. Glass is an amorphous solid which is a non-crystalline and transparent. In addition, it has technological and decorative use. The most known and historically oldest types are silicate glasses according to the chemical composition of silica and the basic component of the sand [1]. Color coating includes many components. One of the most important material is boron. Boron is utilized in fiberglass production in combination with heat resistant borosilicate glasses such as automotive and laboratory equipments. Borosilicate glass is acceptable since the addition of boron oxide reduces the expansion coefficient, thereby increasing the thermal shock resistance of the glass. [2-5]. Ulexite is a borate mineral. Ulexite concentration is commercially substantial since boron compounds are evaluated to produce material for many applications of the industry. Ulexite is appeared in evaporite deposits and the precipitated ulexite usually forms a "cotton ball" tuft. Ulexite belongs to the pentaborate group since it has five boron atoms. Ulexite crystals include three structural groups. These are named pentaborate polyanions, sodium coordinated octahedra and calcium coordinated polyhedra. These groups are shared together and cross linked by hydrogen bonding [6-10]. Potassium dichromate is a common inorganic chemical reactant, most commonly used as an oxidizing agent in a variety of laboratory and industrial applications. [11-15].

In this study, ulexite as a boron source and potassium dichromate are used as main additives to enhance the properties of organic coatings. On the other hand, methacylate based surfactant was used to improve the hydrophobicity effect. Taguchi method was applied as an optimization method to find optimum process conditions between the materials. In conclusion, it was seen that the usage of additives affected the decorative glass organic coatings in terms of hydrophobicity, drying, cross-cut, hiding, visuality and thermal properties.

\section{Experimental}

\subsection{Materials}

Ulexite $\left(\mathrm{NaCaB}_{5} \mathrm{O}_{6}(\mathrm{OH})_{6} \cdot 5 \mathrm{H}_{2} \mathrm{O}\right)$ was supplied from Eti Maden Operations Bandırma Boron and Acid Factories-Turkey and surfactant was supplied from DuPont. Potassium dichromate $\left(\mathrm{K}_{2} \mathrm{Cr}_{2} \mathrm{O}_{7}\right)$ was used as Sigma-Aldrich, $99.5 \%$ of purity.

\subsection{Methods}

Experiments were optimized according to Taguchi Method. Firstly, organic coatings samples were prepared by using ulexite and other additives (Table 1). The additives were taken as basis $100 \mathrm{~g}$ water based organic coatings $(0-6 \%$, w/w). Potassium dichromate was used as color material. Viscosities of the samples were measured by using viscosimeter (Lamy Rheology) at 250 rpm during 20 seconds and then, samples were pulled off on the glass surface which was disinfected before. After waiting 24 hours, samples on the glass were observed and some quality tests were applied. According to test results, optimum sample was evaluated with comparing optimization program result.
Table 1. Experimental set for preparation of organic coatings as concentration (\%) (Level 1: 0\%; Level 2: 3\%; Level 3: 6\%)

\begin{tabular}{cccc}
\hline No & Ulexite (\%) & Clariant $(\%)$ & $\mathbf{K}_{2} \mathbf{C r}_{2} \mathbf{O}_{7}(\%)$ \\
\hline 1 & 0 & 0 & 0 \\
\hline 2 & 0 & 3 & 3 \\
\hline 3 & 0 & 6 & 6 \\
\hline 4 & 3 & 0 & 3 \\
\hline 5 & 3 & 3 & 6 \\
\hline 6 & 3 & 6 & 0 \\
\hline 7 & 6 & 0 & 6 \\
\hline 8 & 6 & 3 & 0 \\
\hline 9 & 6 & 6 & 3 \\
\hline
\end{tabular}

\subsection{Applied Tests}

Cross-cut test, determination of viscosity using rotary viscometers, evaluating degree of blistering, drying, hiding power and hydrophobicity tests were applied to organic coatings. Also, TG-DTA (Thermal Gravimetric-Differential Thermal Analysis) (Perkin Elmer Instruments Diamond TG/DTA Thermogravimetric/Differential Thermal Analyzer, Technology by SII) and SEM (Scanning Electron Microscope) (Zeiss EVOLS 10) analysis were applied for characterization. The samples were coated with gold by using SEM coating device (Quorum SC7620) before analysis. TG-DTA and SEM were used to obtain flame retardancy and physical morphologies of organic coatings, respectively.

\section{Results and Discussion}

Taguchi method is a statistical method for orthogonal arrays with a special design by using a small number of experiments to improve the quality of products and to decrease cost in engineering applications [16]. Taguchi method is the traditional approximation used in quality control. However, most previous optimizaton applications have used only with a single-response problem. The problems which have multi-response have taken only limited attention. There are solutions and proposes in Taguchi method on quality for these problems by using the optimization [17]. In addition, it is known that the experimental sequence is randomized to minimize the effects of uncontrolled parameters by various methods [18]. In Taguchi Method, the experimental results are converted into a signal-to-noise $(\mathrm{S} / \mathrm{N})$ ratio. This method utilizes the $\mathrm{S} / \mathrm{N}$ ratio as a measure of quality parameters deflecting from or nearing to the required values. There are three groups of these quality parameters in this analysis, for instance, One of the lower, the higher or the nominal values is the better. The equation used for calculating of this ratio was presented below [19] as Eq. 1:

"Smaller is the better" equation was given as Eq. (1):

$\mathrm{S} / \mathrm{N}(\eta)=\left(-10 \log _{10} \frac{1}{\mathrm{n}} \sum_{\mathrm{i}=1}^{\mathrm{n}} \mathrm{y}_{\mathrm{i}}^{2}\right)$

where $y_{i}$ is sighted response and $n$ means the replications.

"Nominal is the best" means that the nominal value and its variation are minimum as Eq. (2): 
$\mathrm{S} / \mathrm{N}(\eta)=\left(-10 \log _{10} \frac{\mu^{2}}{\sigma^{2}}\right)$

where $\mu$ is mean and $\sigma$ shows variance.

"Higher the better" means that the larger value is preferred as Eq (3):

$\mathrm{S} / \mathrm{N}(\eta)=\left(-10 \log _{10} \frac{1}{\mathrm{n}} \sum_{\mathrm{i}=1}^{\mathrm{n}} \frac{1}{\mathrm{y}_{\mathrm{i}}^{2}}\right)$

where $\mathrm{y}_{\mathrm{i}}$ is sighted response and $\mathrm{n}$ shows replications.

Taguchi indicated a standard method to optimize the process characteristics [20]. As a result of the optimization study, it was determined that the quality during the preparation of organic coating was significantly improved in terms of consistency and spreadability. When considered in terms of cost, it was concluded that the cost of additives added to the organic coating mixture was quite low, as well as improving the properties, and the cost was significantly reduced. Viscosity results were used as output in optimization method and the graphs were plotted by using viscosity values [21] (Table 2 ).

Table 2. Viscosity results for organic coatings

\begin{tabular}{cc}
\hline No & $\begin{array}{c}\text { Viscosity } \\
\text { (mPa.s) }\end{array}$ \\
\hline 1 & 1375 \\
\hline 2 & 1241 \\
\hline 3 & 1168 \\
\hline 4 & 1642 \\
\hline 5 & 1269 \\
\hline 6 & 1307 \\
\hline 7 & 1527 \\
\hline 8 & 1225 \\
\hline 9 & 1233 \\
\hline
\end{tabular}

Figure 1 showed a Taguchi graph of the experiments. The optimal value was specified with using this method for 3 characteristics and 3 levels. The optimum blend was Experiment 4 with smaller the better choice in Taguchi method. Because, considering the spreadability of the doped organic coating to the surface, the smallest best model in terms of viscosity was selected in the optimization program. As seen in Figure 1, considering the values where the curves were minimum for each parameter, experiment 2-1-2 (medium-lowest-medium) (3\%-0\%-3\%) corresponded to experiment number 4 . Here, parameters A, B and $\mathrm{C}$ showed the concentration of ulexite, clariant and $\mathrm{K}_{2} \mathrm{Cr}_{2} \mathrm{O}_{7}$ in the range of $0 \%$ and $6 \%$, respectively. Also, $\mathrm{x}$ and $\mathrm{y}$ axes showed parameter levels $(0-6 \%)$ and mean of $\mathrm{S} / \mathrm{N}$ ratios, respectively. As a result, it was seen that the optimum point was determined by entering the viscosity values of all experiments into Taguchi program as an optimization method.

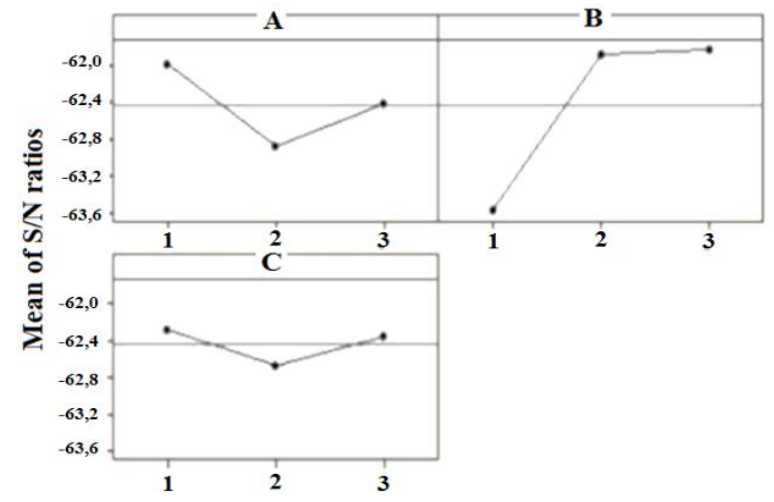

Figure 1. Mean of S/N ratios and parameter level binary graphs of Taguchi method for organic coatings

Wettability is an substantial speciality of solid surfaces from both basic and practical sights. Hydrophobicity test was applied to look at the reflex of the organic coatings against the water. Figure 2 showed the result of hydrophobicity test for Experiment 4. Organic coatings containing hydrophobic material was dripped on dry surface as $0,1 \mathrm{~mL}$ and evaluated as visuality. As a result, surface had hydrophobic property in dry organic coatings film. Drying test was applied to measure drying quality of the organic coatings. According to standards, each coated test panel was treated in a horizontal position with circulation of air for the specified time under the specified process conditions for drying of organic coatings [22]. For the application of the drying test, firstly organic coatings were applied to the surface for 24 hours and it was tested whether the coatings were dried by rotating the thumb 360 degrees on coating. Figure 3 showed the result of drying test for experiment 4.

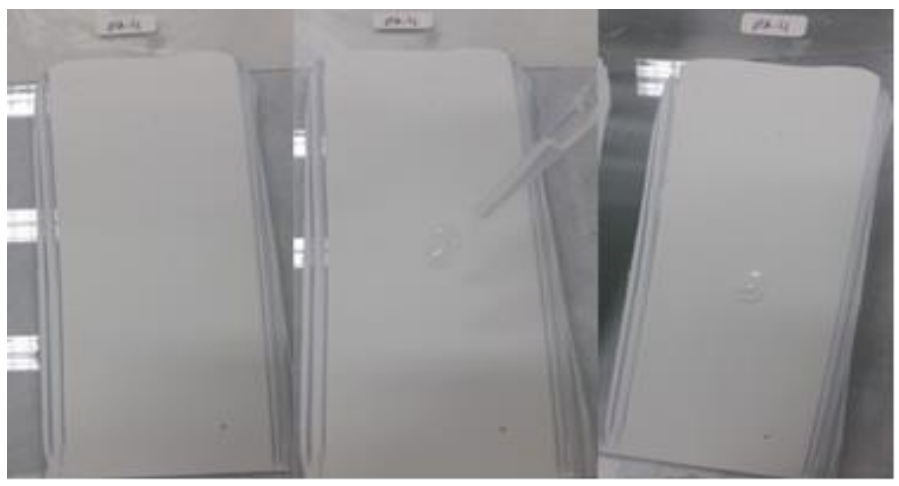

Figure 2. Hydrophobicity test result for optimum experiment (No:4)

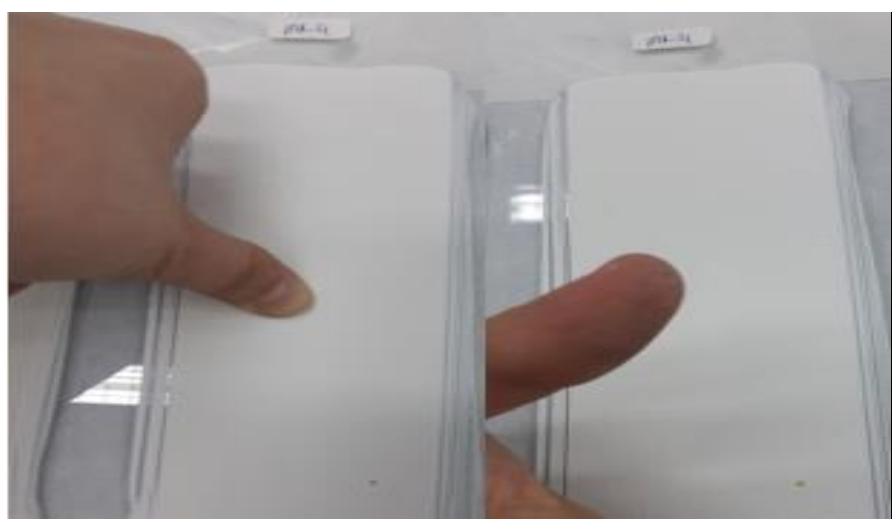

Figure 3. Drying test result for optimum experiment (No:4) 
Adhesion relates on interfacial surface energy, geometry and elasticity coefficients [23]. The test named as cross-cut was applied to measure strength of the organic coatings. The film of $1.5-2 \mathrm{~cm}$ long $45^{\circ}$ angle on the two diagonals and the line was marked on the side edges $135^{\circ}$ angle for cross-cut test [24]. Adhesive tape was marked perpendicular to the surface with a jerk. As a result of the tests, scratches edges fully homogeneous, none of the square formed by combing shedding was sighted. Figure 4 showed the result of cross cut test, positively.

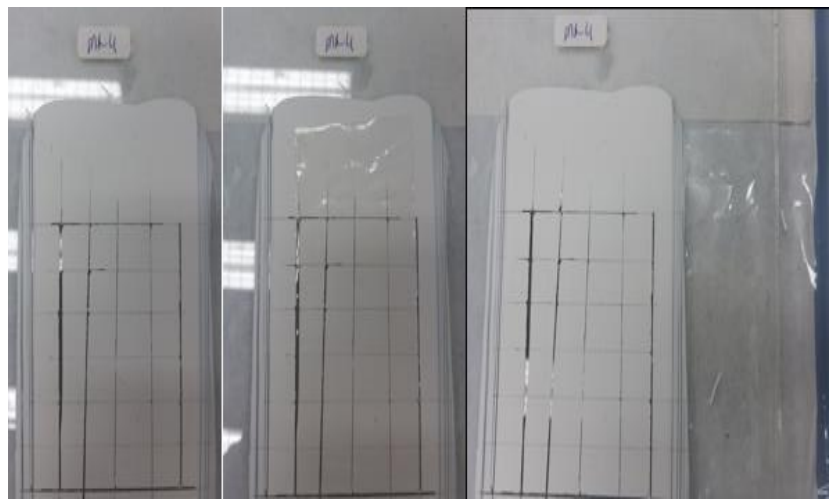

Figure 4. Cross-cut test result for optimum experiment (No:4)

For hiding power test, the special papers were used to measure hiding scale of the organic coatings and degree of blistering [25]. Figure 5 showed the hiding power test and the test result showed that glass organic coatings had high hiding power for applications especially construction industry.

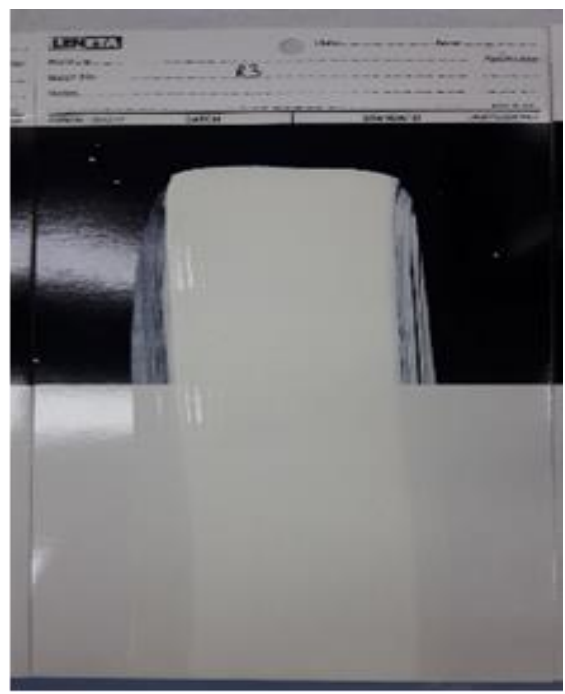

Figure 5. Hiding test result for optimum experiment (No: 4)

Whereas TG only showed changes by mass loss, DTA also measured the changes in material where no mass loss occurs. TGDTA curves showed that the decomposition of water-based acrylic coatings occurred in such way that in first step the hydration water was lost. After this step, the decomposition of additives was observed. These events appeared as endothermic processes in DTA curve. The samples $(6-10 \mathrm{mg})$ were put into a pan and heated between $20-500^{\circ} \mathrm{C}$ at $10^{\circ} \mathrm{C} / \mathrm{min}$ under $\mathrm{N}_{2}$ flow. The thermal profiles were determined under isothermal conditions. TG analysis of as-prepared powder gave 70-97\% a sharp weight loss between $20-500^{\circ} \mathrm{C}$ for organic coatings. After heating, one endothermic peak occurred approximately $400^{\circ} \mathrm{C}$. e-ISSN: 2148-2683
This was consistent with the DTG analysis. (Figure 6). As a result, it was seen the process was affected the water loss of crystallization through condensation of $\mathrm{B}-\mathrm{OH}$ groups $\mathrm{C}$. The results were compatible as seen from the results of different materials used in glass paintings [26-28].

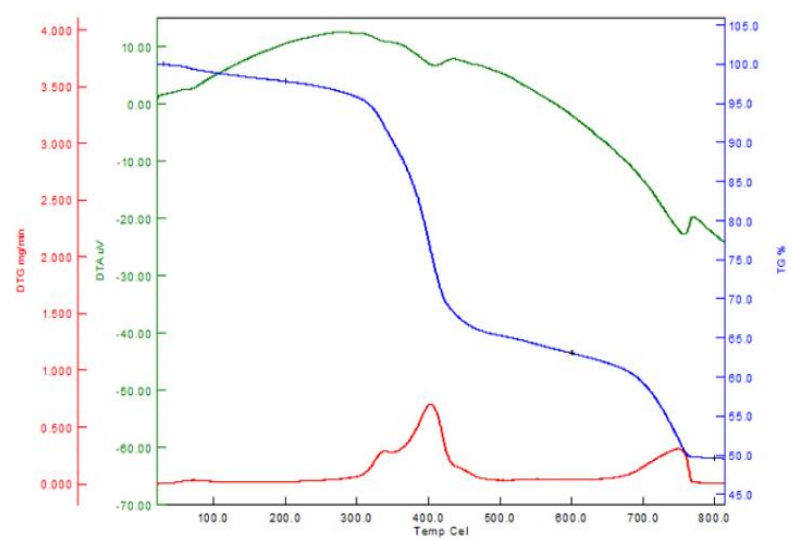

Figure 6. TG-DTA analysis of optimum experiment (No: 4)

SEM results showed that the physical morphology of reference coating was similar with optimum sample of coatings (Figure 7). The size distribution changed because of the agglomerated structure in reference coating. Regular particles were formed in optimum structure. It was seen that regularity was a significant parameter to use acrylic coatings on various surfaces.

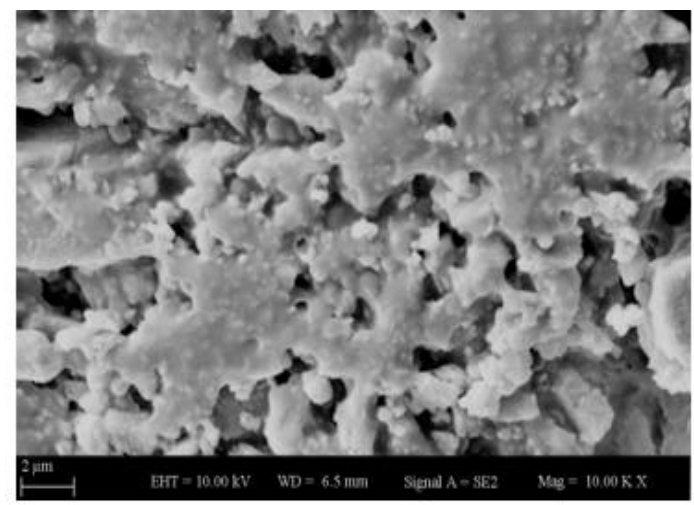

Figure 7. The results of SEM analysis (x10000) for optimum experiment (No: 4)

\section{Conclusion}

As a result, optimum parameters were specified with using Taguchi as an optimization method to increase the coating quality. It had been observed that the optimum parameters corresponded to Experiment 4. The test results (hydrophobicity, cross-cut, hiding power etc.) showed that the additives improved the physical properties of water-based glass organic coatings. TGDTA and SEM results determined the thermal and morphological properties of coatings, respectively. It was seen that organic coatings prepared with boron-based additives could be evaluated in industrial applications.

\section{Conflict of Interest}

The authors have declared no conflict of interest. 


\section{References}

[1] Pavlyukevich, Y. G. Levitskii, I. A., Mazura, N. V. Use of colemanite in glass fiber production, Glass and Ceramics, 66(9-12), (2009), 345-349.

[2] Woods, W. G. An introduction to boron: history, sources, uses, and chemistry, Environmental Health Perspectives, 102, (1994), 5-11.

[3] Turkez, H. Geyikoglu, F. Tatar, A. Keles, M. S., Kaplan, I. The effects of some boron compounds against heavy metal toxicity in human blood, Experimental and Toxicologic Pathology, 64(1-2), (2010), 93-101.

[4] Muller, F. B., McSweeney, G. Toxicity of borates to turnips, New Zealand, Journal of Experimental Agriculture, 4(4), (1976), 451-455.

[5] www. etimaden.gov.tr, Accessed Date: 23.07.2020.

[6] Küçük, Ö., Kocakerim, M. M. Optimization of dissolution of ulexite in water saturated with sulphur dioxide, Chemical Engineering and Processing: Process Intensification, 44(9), (2005), 1005-1011.

[7] Topaksu, M. Correcher, V. Garcia-Guinea, J., Yüksel, M. Effect of heating rate on the thermoluminescence and thermal properties of natural ulexite, Applied Radiation and Isotopes, 95, (2015), 222-225.

[8] Stoch, L., Waclawska, I. Thermal decomposition of ulexite, Journal of Thermal Analysis, 36, (1990), 2045-2054.

[9] Ruoyu, C. Jun, L. Shuping X., Shiyang, G. Thermochemistry of ulexite, Thermochimica Acta, 306(1-2), (1997), 1-5.

[10] Topaksu, M. Correcher, V., Garcia-Guinea, J. Thermoluminescence sensitivity of ulexite after UV irradiation, Nuclear Instruments and Methods in Physics Research Section B: Beam Interactions with Materials and Atoms, 349, (2015), 17-23.

[11] https://cameochemicals.noaa.gov, Accessed Date: 23.07.2020.

[12] https://echa.europa.eu, Accessed Date: 23.07.2020.

[13] https://www.cdc.gov, Accessed Date: 23.07.2020.

[14] http://www.ilo.org, Accessed Date: 23.07.2020.

[15] https://clinicaltrials.gov, Accessed Date: 23.07.2020.

[16] Vankanti, V. K., Ganta, V. Optimization of process parameters in drilling of GFRP composite using Taguchi method, Journal of Materials Research and Technology, 3(1), (2014), 35-41.

[17] Tong, L. I. Su, C. T., Wang, C. H. The optimization of multiresponse problems in the Taguchi method, International Journal of Quality \& Reliability Management, 14(4), (1997), $367-380$.

[18] Kasapoğlu, K. N., Demircan, E., Özgüven, M. G., Özçelik, B. Modeling and optimization of supercritical $\mathrm{CO}_{2}$ extraction of natural pigments from black rosehip using response surface methodology, European Journal of Science and Technology, 20, (2020), 16-23.

[19] Phadke, S. M. Quality engineering using robust design, Prentice Hall, Englewood Cliffs, New Jersey, USA, 1989.
[20] Kaushik, G., Thakur, I. S. Isolation and characterization of distillery spent wash color reducing bacteria and process optimization by Taguchi approach, International Biodeterioration \& Biodegradation, 63(4), (2009), 420-426.

[21] ISO 2884-2. Paints and varnishes-Determination of viscosity using rotary viscometers-Part 2: Disc or ball viscometer operated at a specified speed (2003).

[22] BS EN ISO 9117. Paints and varnishes-Drying Tests (2009).

[23] Kendall, K. The adhesion and surface energy of elastic solids, Journal of Physics D: Applied Physics, 4, (1971), 11861195 .

[24] BS EN ISO 2409. Method of test for paints. Cross-Cut Tests (2013).

[25] ASTM D714-02. Standard test method for evaluating degree of blistering of paints (2017).

[26] Guzik, F. Hierarchical zeolites: synthesis and catalytic properties, Microporous and Mesoporous Materials, 259, (2018), 33-45.

[27] Davis, M., Lobo, R. F. Zeolite and molecular sieve synthesis, Chemistry of Materials, 4, (1992), 756-768.

[28] Acaral1, N., Oktay, R. An investigation on acrylic organic coatings including colemanite and zeolite for glass materials, Celal Bayar University Journal of Science, 14(3), (2018), 257-260. 